\title{
TRAFFIC \\ IN ASIAN WOMEN
}


NEXT WAVE: New Directions in Women's Studies

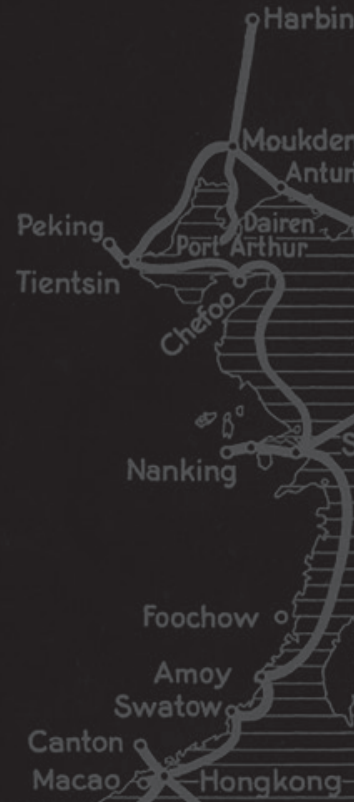

Calcutta

Hano:

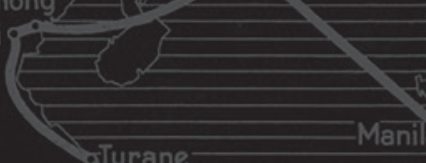

Jurane

Bangkok

-Madras

-Pondicherry
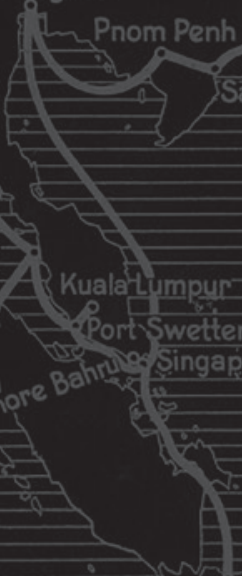
LAURA HYUN YI KANG

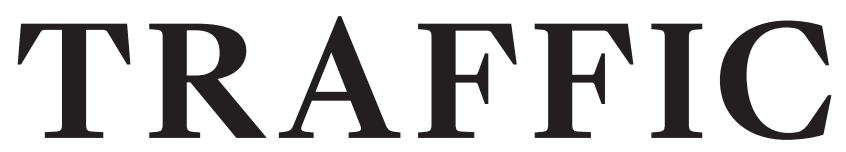

IN ASIAN

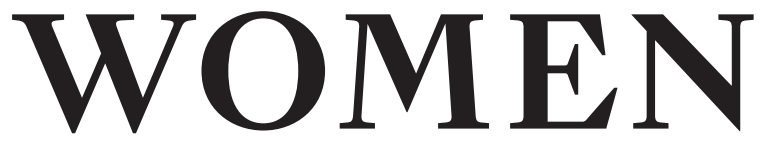


(C) 2020 Duke University Press. All rights reserved

Printed in the United States of America on acid-free paper $\infty$

Designed by Courtney Leigh Baker

Typeset in Portrait, Sang Bleu, and Futura by Westchester Publishing Services

Library of Congress Cataloging-in-Publication Data

Names: Kang, Hyun Yi, [date] author.

Title: Traffic in Asian women / Laura Hyun Yi Kang.

Other titles: Next wave (Duke University Press)

Description: Durham : Duke University Press, 2020. | Series: Next wave | Includes bibliographical references and index.

Identifiers: LCCN 2019054644 (print) | LCCN 2019054645 (ebook)

ISBN 978I478008804 (hardcover)

ISBN 9781478009665 (paperback)

ISBN 978 I47780I2283 (ebook)

Subjects: LCSH: Women-Asia-Social conditions-2oth century. | Women-Violence against

-Asia. | Women's rights-Asia-History-20th century. | Comfort women. | Women and war

-Asia-2oth century.

Classification: LCC HQI726 .K36 2020 (print) | LCC HQI726 (ebook) | DDC 305.42095/0904-dc23

LC record available at https://lccn.loc.gov/2019054644

LC ebook record available at https://lccn.loc.gov/2019054645

Duke University Press gratefully acknowledges the support of the University of California, Irvine, UCI Humanities Commons, which provided funds toward the publication of this book.

Cover art: Map of "The Itinerary of the Commission of Enquiry" (detail), Enquiry into Traffic in Women and Children in the East, 1932. 
for my mother \& for Junsu and Minsu 
This page intentionally left blank 